\title{
Standardized catch rate of cockfish, Callorhinchus callorynchus, in a bottom trawl fishery of Patagonia: Is it possible its use as a predictor of abundance trend?
}

\author{
Juan F. Bernasconi, María Raquel Perier, Edgardo E. Di Giácomo
}

\author{
Grupo de Estudio de Peces Cartilaginosos (CONDROS), Instituto de Biología Marina y Pesquera "Alte. Storni". \\ (Güemes 1030, zip: 8520, San Antonio Oeste, Rio Negro, Argentina, Tel: (54) 02934-430764) \\ *Corresponding author: jfbernasconi@yahoo.com.ar
}

\begin{abstract}
The catch per unit of effort (CPUE) data of cockfish, Callorhinchus callorynchus, during 1986-2011 was evaluated for the bottom trawl fishery of the San Matías gulf (Patagonia, Argentina). The objective of this work was to detect what are the factors related to fishery dynamic that affect catch rate of cockfish and to assess standardized CPUE by General linear models (GLMs) and General linear mixed models (GLMMs) as a relative abundance index. The annual trend of the catch rate indicated an increase during the evaluated period. The nominal CPUE and the indices standardized by the Delta-GLM and Delta-GLMM showed the same annual trend, with increases of $57 \%, 61.1 \%$ and $60.7 \%$, respectively. The LogNormal models have the best-fit model and explained $23.5 \%$ of the total variability. The factors year, month, depth and hake CPUE explained the highest variability. The analysis of the models indicated that the catch rate of cockfish is subject to the lack of an homogeneous distribution of the fishing effort during different years, months and vessels. This was related to the fleet dynamic searching the targets species. The increasing trend of CPUE and landings would be indicating an increase in effort directionality to the cockfish in the last decade.
\end{abstract}

Descriptors: Standardized CPUE, Holocephali, Chondrichtyans bycatch, GLM, GLMM, Chimaeroids.

\section{Resumo}

Dados de captura por unidade de esforço (CPUE) do peixe-galo Callorhinchus callorynchus foram avaliados para a pesca de arrasto de fundo no Golfo de San Matías (Patagonia, Argentina), durante o período 1986-2011. Os objetivos do trabalho foram identificar quais os fatores relacionados à dinâmica pesqueira que afetam a taxa de captura do peixe-galo e verificar a viabilidade em utilizar dados de CPUEs padronizadas pelos Modelos Lineares Gerais (GLM) e Modelos Lineares Gerais Mistos (GLMMs) como índices de abundância relativa. A tendência anual da taxa de captura indicou um aumento durante o período avaliado. A CPUE nominal e os índices padronizados pelo Delta-GLM e Delta-GLMM apresentaram a mesma tendência anual, com aumentos de $57 \%, 61.1 \%$ e $60.7 \%$, respectivamente. Os modelos LogNormal foram os de melhor ajuste e explicaram $23,5 \%$ da variabilidade total dos dados. Ano, mês, profundidade e "hake" CPUE foram os fatores mais explicativos. A análise dos modelos indicou que a taxa de captura do peixe-galo está ligada à falta de distribuição homogênea do esforço de pesca durante os diferentes anos, meses e navios. Este fato esteve relacionado à dinâmica das frotas na busca das espécies alvo. A tendência crescente no aumento das CPUE e descargas em terra estaria indicando a mudança do esforço de pesca direcionado ao peixe-galo na última década.

Descritores: CPUE padronizadas, Holocephali, Captura acessória de condrictes, GLM, GLMM, Chimeroides. 


\section{INTRODUCTION}

The classification of chondrichthyans (sharks, batoids and chimaeras) as vulnerable species to fishing exploitation has generated worldwide concern about their populations status (HOLDEN, 1973; HOENING Y GRUBER, 1990; STEVENS et al., 2000). A declining abundance trend of chondrichthyan populations has been documented in several fisheries (MIRANDA and VOOREN, 2003; BAUM and MYERS, 2004; CAMHI et al., 2008; BAUM and BLANCHARD, 2010; FERRETTI et al., 2013), and particular cases of local extinctions have been recorded (BRANDER, 1981; CASEY and MYERS, 1998; DULVY et al., 2000; VOOREN and KLIPPEL, 2005). Their life-history characteristics (slow growth, late sexual maturity, low fecundity and high longevity) associated with increased catches in the recent years are the principal causes of their vulnerability. However, chondrichthyan species and their populations have different degrees of vulnerability due to their different spatial distribution during different ontogenetic stages, the current commercial interest and the particular characteristics of each fishery. In this sense, stability of chondrichthyan populations that are commercially harvested has been documented in some occasions (WALKER, 1998; MINISTRY FOR PRIMARY INDUSTRIES OF NEW ZEALAND, 2011; BARNETT et al., 2012; CARLSON et al., 2012).

Quantification of the impacts of fishery exploitation and abundance estimation of fish stocks are two of the principal goals of fishery assessment, that allow to implement conservation and management measures. In the majority of fisheries, the most common source of information to infer the population abundance trend is the catch per unit of effort (CPUE) from commercial fisheries (HILBORN and WALTERS, 1992; MAUNDER and PUNT, 2004). However, the nominal CPUE is seldom proportional to stock abundance over their whole history of exploitation and their entire geographic range, particularly for non-target species, because several factors affect catch rates (MAUNDER et al., 2006). Therefore, standardization of CPUE considering the effect of these factors and the particular dynamic of each fishery and each species (PUNT et al, 2000; MAUNDER et al., 2006; BRACCINI et al, 2011) is necessary to construct reliable abundance indices (HILBORN and WALTERS, 1992, MAUNDER and PUNT, 2004). The studies about the abundance trends of chondrichthyans that are caught as bycatch and the factors that influence their catch rate have been increased worldwide both in multispecies and monospecies fisheries (PUNT et al. 2000; SIMPFENDORFER et al., 2002; BAUM et al., 2003; AIRES da SILVA et al., 2008; BAUM and BLANCHARD, 2010; CARVALHO et al., 2010; BRACCINI et al., 2011; BARNETT et al., 2012; CARLSON et al., 2012; BROMHEAD et al., 2012, TRAVASSSOS TOLLOTTI et al., 2013).

Chimaeroids (subclass Holocephali), are a group of chondrichthyan that include species caught as bycatch in several worldwide fisheries whose target species are bony fishes (DI GIÁCOMO and PERIER, 1991; MOURA et al., 2004; MINISTRY FOR PRIMARY INDUSTRIES OF NEW ZEALAND, 2011; BARNETT et al., 2012). Particularly, the species of the genus Callorhinchus are captured and commercially exploited in all their distribution range in the south hemisphere: the elephant fish C. milii in New Zealand (FRANCIS, 1998) and Australia (BRACCINI et al., 2011), the St Joseph C. capensis in South Africa (FREER and GRIFFITHS, 1993) and the cockfish C. callorynchus in Argentina (DI GIÁCOMO and PERIER, 1991) and Chile (ALARCÓN et al., 2011).

The abundace trend of $C$. milii has been evaluated in Australia and New Zealand. In 1986, the C. milii stocks of New Zealand were declared overexploited, but then they showed recovery signs up to reach historic landing volumes, reaching the maximum landings of 1,300-1,400 tons approximately between 2007-2010 (FRANCIS, 1998; MINISTRY FOR PRIMARY INDUSTRIES OF NEW ZEALAND, 2011). In Australia, BRACCINI et al. (2011) evaluated the use of the standardized CPUE as an index of relative abundance for $C$. milii, and unlike the New Zealand case, they detected a decreasing tendency during the study period from 1976 to 2006 .

C. callorynchus is distributed from Sao Paulo state, Brazil (FIGUEIREDO, 1977), to Beagle Channel (LÓPEZ et al., 2000) along the Atlantic Ocean. In Argentina, the cockfish landings represent the $97 \%$ of the total Southwestern Atlantic catches, out of which $32 \%$ are landed in the port of San Antonio Oeste (40 $48^{\circ} \mathrm{S}-64^{\circ} 52^{\prime} \mathrm{W}$ ) (SANCHEZ et al., 2012). There has been an increase in Argentinean landings from 1992 to 2011. The lowest landing was 490 tons recorded in 1992, the highest one was 2,780 tons in 2009 and the annual average for the whole period was 1,600 tons (SÁNCHEZ et al, 2012).

The San Matías Gulf (SMG) $\left(41-42^{\circ} \mathrm{S}, 64-65^{\circ} \mathrm{W}\right)$ (Figure 1) is a semienclosed basin with relatively isolated waters separated from the adjacent continental shelf by an $80 \mathrm{~m}$-deep sill and constitutes a particular ecosystem of Northern Patagonia (RIVAS and BEIER, 1990; GAGLIARDINI and RIVAS, 2004; PERIER et al, 2011). An industrial bottom trawl fishery has been developed in 
the SMG waters since 1971 (DI GIÁCOMO and PERIER, 1992), which operates in the port of San Antonio Oeste. The target species of this fishery is the common hake, Merluccius hubbsi, and 18 chondrichthyan species are frequently caught as bycatch, being the cockfish, $C$. callorynchus, the most caught and landed cartilaginous fish (PERIER et al., 2011). During most of the fishery history, the cockfish was the second species that contributes the most to the caught volumes (DI GIÁCOMO and PERIER, 1991). The fishery management is considered as monospecific because it is only performed based on the target species. The cockfish's biological characteristics and its distribution have been studied extensively in the SMG (DI GIÁCOMO, 1992; DI GIÁCOMO and PERIER, 1994; DI GIÁCOMO et al., 1994; DI GIÁCOMO and PERIER, 1996). The cockfish's biomass and commercial exploitation have also been evaluated from the beginning of the fishery until 1986, and the species was considered underexploited due to its low incidence in the total catches of the fleet (DI GIÁCOMO and PERIER, 1991). However, this pattern might have changed due to the current trend of increase of chondrichthyan catches in Argentina. In this context, even though the last SMG fishery period (1999-2011) has been characterized by the addition of the silver warehou (Seriolella porosa) as a seasonal target species (PERIER and DI GIÁCOMO, 2002; ROMERO et al., 2013), the catch levels of $C$. callorynchus have reached the highest historic values in terms of landing volumes (MILLAN, 2011; SÁNCHEZ et al., 2012) (Figure 2).

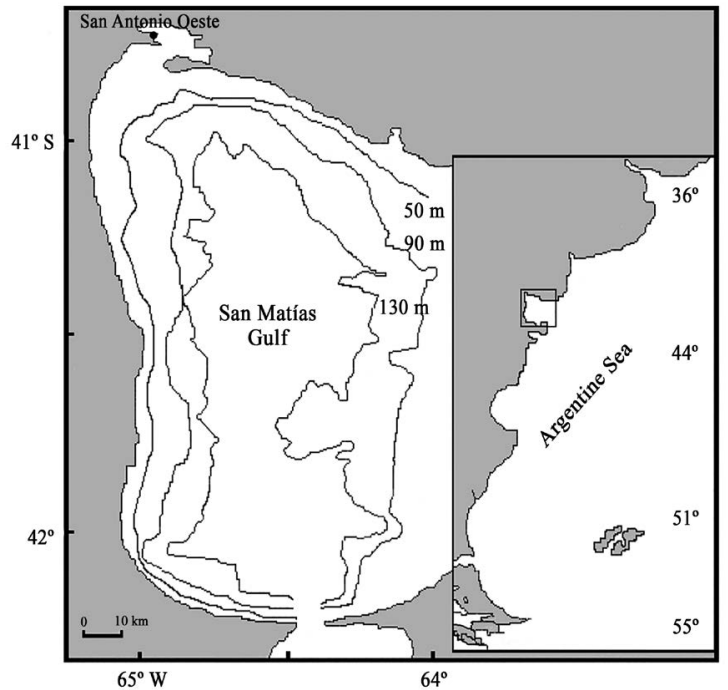

Figure 1. Geographical localization of the study area: San Matías Gulf, Argentina.

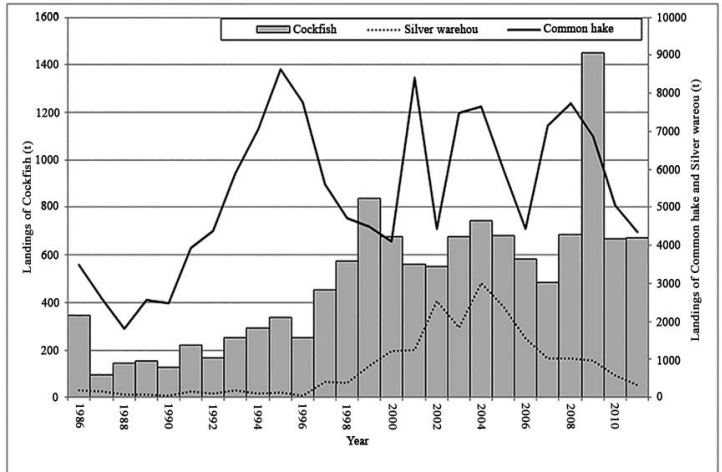

Figure 2. Commercials landings of cockfish, common hake and silver warehou in the San Matías Gulf, 1986-2011.

There is not information about time series of abundance from fishery-independent data for C. callorynchus, except for an isolated abundance estimation in 1986 (DI GIÁCOMO and PERIER, 1991). Therefore, assessments of population trend must be solely based on CPUE fishery-dependent data. With this aim, studies that confirm the validity of using the standardized CPUE as an index of relative abundance trend are needed. The objective of this work is to detect what are the factors related to fishery dynamic that affect catch rates of cockfish and assess the use of standardized CPUE as a relative abundance index for this species during 1986-2011.

\section{MATERIAL AND METHODS}

\section{DATA SOURCES}

The analyzed data was obtained from the Fishery Statistics of the Dirección de Pesca de la Provincia de Río Negro (Fisheries Directorate of the Rio Negro Province). The information consisted of logbook data from 1986 to 2011 for the bottom trawl fleet of the SMG. The following information was obtained for each fishing trip: a) Vessel name, b) Arrival date and time, c) Hauls number, d) Effective Fishery hourse) Maximal and minimal depths of trawl in meters (m), f) Total weight of landed common hake in kilograms $(\mathrm{kg}), \mathrm{g})$ Total weight of landed cockfish in $\mathrm{kg}$ and $\mathrm{h}$ ) Total weights of other landed species in $\mathrm{kg}$. Furthermore, a database of the Dirección de Pesca with the main features of the fleet was analyzed. The following information was obtained for each vessel: engine power (horsepower, HP), vessel length, gross register tonnage (GRT), ship company and construction date. A preliminary analysis was conducted and information of the database was filtered to detect obvious errors or outliers. Fishing 
trips with erroneous data and vessels with less than five trips were removed. The nominal CPUE was calculated as declared cockfish kilograms per effective fishing hours for each vessel on each fishing trip.

\section{Proposed Statistical Models}

Various methods have been developed to standardize CPUE in different fisheries. However, the most common method is the use of Generalized Linear Models (GLM) (MAUNDER and PUNT, 2004) and recent applications for sharks have included extensions of Generalized Linear Mixed Models (GLMM) (BAUM and BLANCHARD, 2010; BRACCINI et al., 2011). These models allow to estimate the catch rate (response variable) with a linear combination of a set of explanatory variables.

Non-target CPUE data are often characterized by a high proportion of zero catches and left-skewed distributions (ORTIZ and AROCHA, 2004). In this study, there was a left-skewed distribution and the proportion with zero catches of cockfish was of $16 \%$ (1480 trips). Therefore, a two part Delta-model was used (VIGNAUX, 1994). This method is convenient because it calculates separately the probability of a non-zero observations, the CPUE for the non-zero data and them combines the two to estimate the annual CPUE trend. The delta-approach has been described extensively in other papers (LO et al., 1992; MAUNDER and PUNT, 2004; ORTIZ and AROCHA, 2004). Indices of annual abundance were estimated by modelling the probability of the nonzero catch assuming a model with a binomial error distribution and a logit link. The distribution of the positive cockfish catches was evaluated by examining the appropriateness of the distribution assumed for errors. Generally, in fisheries research, if the catch rate data are characterized by highly skewed positive observations, the most frequently assumed distributions are LogNormal and Gamma (PUNT et al., 2000; BRYNJARSDÓTTIR and STEFÁNSSON, 2004; ORTIZ and AROCHA, 2004; DICK, 2004). Thus, GLMs using these two error structures were examined for the positive data set: (1) a LogNormal model in which the logarithm of the positive catch rate ( $\log$ CPUE) is assumed to be normally distributed and an identity link function is used (GAVARIS, 1980); and (2) a Gamma model in which the dependent variable (CPUE) is gamma distributed and a $\log$ link function is used.

GLMMs are an extension of the GLMs used to model fishery catch rates, which allow the analysis of correlated response data (VENABLES and DICHMONT, 2004). First, the standardized catch rate was evaluated with the error structure and the fixed effects selected for the GLM. Then, the same error structure and fixed effects were used in a GLMM using the method of residual maximum likelihood (REML). In this model, individual vessels were treated as a random effect because the fishing trips made by the same vessel can be thought of as repeated measures in a longitudinal analysis (BAUM and BLANCHARD, 2010).

\section{EVALUATED FACTORS}

Factors that most likely influence catch rate were evaluated in a forward stepwise fashion following ORTIZ and AROCHA (2004). First, a null model with no factors entered into the model was run. Models were then fit in a stepwise forward manner adding one independent variable each time. Each factor was ranked from greatest to least reduction in deviance per degree freedom when compared to the null model. The factor with the greatest reduction in deviance was then incorporated into the model provided that the effect was significant at $p<0.05$ based on a $\chi^{2}$ test, and the deviance per d.f. was reduced by at least $1 \%$ from the less complex model (ORTIZ and AROCHA, 2004).

The linear predictor was constructed by examining all the explanatory variables available in the data sources (logbooks and vessels register) (Table 1). Data related to vessel characteristics (engine power, length, GRT) were evaluated as independent fixed factors. Collinearity of explanatory variables was evaluated using the statistical software R with the function vif of the package car (FOX and WEISBERG, 2011) to avoid its inclusion in the model (MAUNDER and PUNT, 2004). As all the technical vessel characteristics had a clear pattern of correlation among each other (vif value $>5$ ), they were excluded from the analysis. Only the vessel length factor was included in the models since it explained the highest percentage of deviance.

Vessel permanence factor and vessel operability factor were calculated following DI GIÁCOMO and PERIER (1992), in order to evaluate whether the fleet behavior influence the cockfish catch rate. These factors were transformed in categorical variables with ranges of permanence and operability (Table 1). Following MAUNDER \& PUNT (2004), the catch rate of common hubbsi and silver warehou also were treated as categorical variables. We prefer the alternative of discretizing this continuous explanatory variables to increase the explanatory power. Interactions were not included in the model due to the absence of data for each interaction. 
Table 1. Evaluated explicatory variables hypothesized to affect catch rates of Cockfish in the SMG bottom trawl fishery of the northern Patagonia.

\begin{tabular}{|c|c|c|c|}
\hline Explanatory variable & Type & Levels & Description \\
\hline Year & Categorical & 26 & $1986-2011$ \\
\hline Month & Categorical & 12 & From January to December \\
\hline Depth & Categorical & 4 & $\begin{array}{l}\text { Maximal depth categories of trawl during the fishing trips } \\
(50-90 \mathrm{~m} ; 91-130 \mathrm{~m} ; 131-165 \mathrm{~m} ;>\text { a } 165 \mathrm{~m}) \text {. }\end{array}$ \\
\hline Vessel name & $\begin{array}{l}\text { Categorical } \\
\text { (random effect) }\end{array}$ & 84 & Bottom trawl vessel with more than five fishing trips. \\
\hline Vessel length & Categorical & 6 & $\begin{array}{l}\text { Vessel length ranges (< a } 16 \mathrm{~m} ; 16-20 \mathrm{~m} ; 21-25 \mathrm{~m} ; 26-30 \mathrm{~m} \text {; } \\
31-35 \mathrm{~m} ;>\text { a } 36 \mathrm{~m})\end{array}$ \\
\hline Vessel HP & Categorical & 6 & $\begin{array}{l}\text { Vessel engine power range in HP (< a } 300 \mathrm{HP} ; 300-360 \mathrm{HP} ; 361-399 \\
\mathrm{HP} \text {; 400-460 HP; } 461-600 \mathrm{HP} ;>\text { a } 600 \mathrm{HP}) .\end{array}$ \\
\hline Vessel GRT & Categorical & 11 & $\begin{array}{l}\text { Gross register tonnage range GRT }(<\text { a } 25 ; 25-40 ; 41-50 ; 51-60 \\
61-70 ; 71-80 ; 81-90 ; 91-100 ; 101-110 ; 111-120 ;>\text { a } 120)\end{array}$ \\
\hline$\%$ of Operability & Categorical & 6 & $\begin{array}{l}\text { Operability percentage ranges during } 1986-2011 \\
(<\text { a } 1 \% ; 1-4 \% ; 4.1-10 \% ; 10.1-20 \% ; 20.1-50 \% ;>\text { al } 50 \%) \text {. }\end{array}$ \\
\hline Permanence & Categorical & 4 & $\begin{array}{l}\text { Numbers of consecutive or alternated fishing trimesters for each } \\
\text { vessel during } 1986-2011 \text { ( } 1 \text { a } 3,4 \text { a } 12 ; 12 \text { a } 24 ;>\text { de } 24 \text { trimesters). }\end{array}$ \\
\hline $\begin{array}{l}\text { Catch rate of common hake } \\
\text { (target species) }\end{array}$ & Categorical & 6 & $\begin{array}{l}\text { Catch rate ranges of common hake }(0-250 \mathrm{~kg} / \mathrm{hs} ; 251-500 \mathrm{~kg} / \mathrm{hs} \text {; } \\
251-500 \mathrm{~kg} / \mathrm{hs} ; 501-750 \mathrm{~kg} / \mathrm{hs} ; 751-1000 \mathrm{~kg} / \mathrm{hs} ;>1000 \mathrm{~kg} / \mathrm{hs})\end{array}$ \\
\hline $\begin{array}{l}\text { Catch rate of silver warehou } \\
\text { (seasonal target species during 2000-2011) }\end{array}$ & Categorical & 7 & $\begin{array}{l}\text { Catch rate ranges of silver warehou }(0 \mathrm{~kg} / \mathrm{hs} ; 1-250 \mathrm{~kg} / \mathrm{hs} ; 251-500 \\
\mathrm{kg} / \mathrm{hs} ; 251-500 \mathrm{~kg} / \mathrm{hs} ; 501-750 \mathrm{~kg} / \mathrm{hs} ; 751-1000 \mathrm{~kg} / \mathrm{hs} ;>1000 \mathrm{~kg} / \mathrm{hs}) .\end{array}$ \\
\hline
\end{tabular}

\section{Model Selection AND FIT}

The total deviance explained cannot be compared among models with different error distributions because the formulation of the deviance is a function of the error distribution. Therefore, the total deviance explained should be interpreted only as an indicator of the goodness of a fit between the observed data and the assumed model, and not as the basis for selecting a particular error distribution (MCCULLAGH and NELDER, 1989). Appropriate fit and diagnostics residuals plots were evaluated to check the underlying assumptions on the error distribution and select the final GLM (MCCULLAGH and NELDER, 1989; MAUNDER and PUNT, 2004; ORTIZ and AROCHA, 2004). Also, the AKAIKE information criteria (AIC) (AKAIKE, 1973) was used to select the final model following DICK (2004). Finally, a likelihood ratio test was made to evaluate significant differences between the GLM and the GLMM with the vessel factor as random effect (CRAWLEY, 2007; ZUUR et al., 2009). All statistical analyses were conducted using the software R, version 2.15.2 (IHAKA and GENTLEMAN, 1996) and the package nlme for the GLMM modelling (PINHEIRO et al., 2012).

\section{RESULTS}

From a total of 9,313 fishing trips conducted between 1986 and 2011, 7,833 contained cockfish catches and were selected for further analysis of the different fishery factors on the cockfish CPUE trends.

A total of 105 bottom trawl vessels operated during the study period, out of which 21 were excluded from the analysis because they conducted five or less trips. The 84 vessels that were evaluated were characterized by: 115 to $800 \mathrm{HP}$ of engine power; 12 to $39 \mathrm{~m}$ of length and 11 to 240 GRT. The mean number of fishing vessels over the year was 13 with a maximum of 20 vessels in 2001 and a minimum of 7 in 1990.

The fleet activity indicators (vessel permanence and vessel operability factors), show that the fleet behavior was unstable during 1986-2011 (Figure 3a and Figure 3b). The $94 \%$ of vessels show less of $50 \%$ of operatibility and only in 6 vessels the operatibility percentage was greater than $50 \%$ (Figure 3b). The vessel with the greatest operatibility was B/P Siempre San Salvador due to the total effective fishing hours $(29,473$ hs in 653 trips). It also had the greatest landings of cockfish (1,632 tons), common hake (15,788 tons) and total catches (24,752 tons). Regarding the permanence of vessels, only 12 vessels fished during more than 24 trimesters, out of which the vessel with the greatest operability fished during 52 continuous trimesters (Figure $3 a$ ).

The selected factors and the deviance tables of the Binomial, LogNormal and Gamma GLMs are shown in Table 2. Each model included the factors that influenced significantly the final model. The LogNormal model 


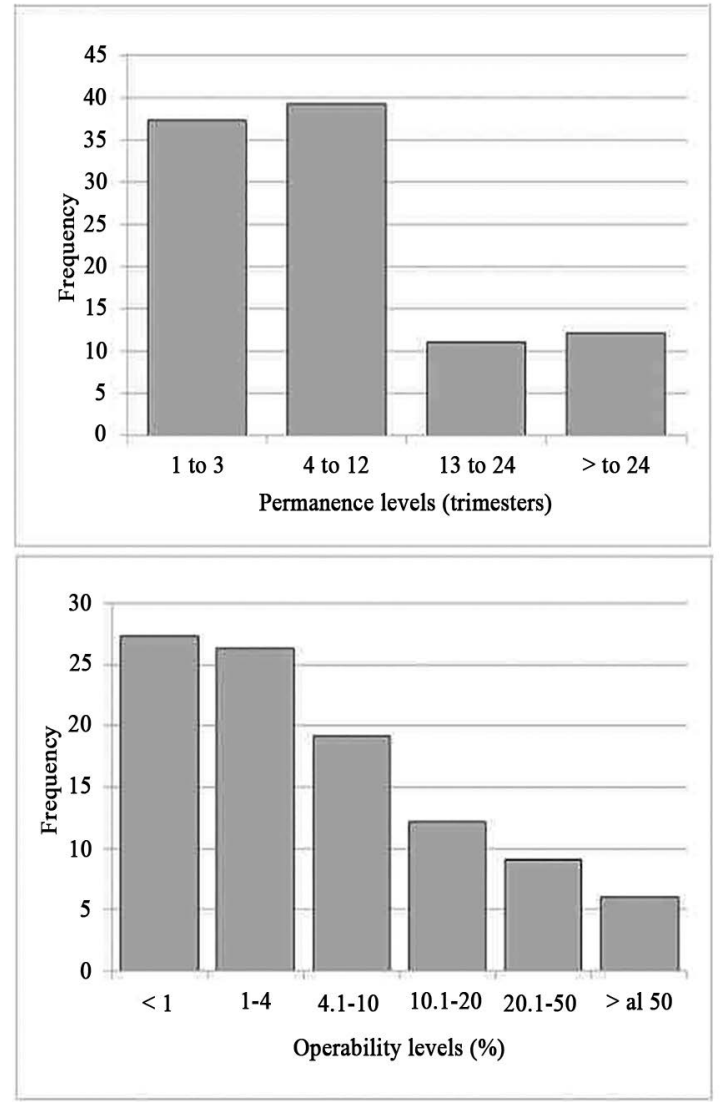

Figure 3. Histograms of 105 vessels with (a) the number of fishing trimester permanence and (b) the levels of factor operability.

explained $23.5 \%$ of the total variability while the Gamma model explained $20.7 \%$ of the total variability.

The fit and diagnostics residuals plots indicated that the LogNormal model is the one that best fits the positive set of CPUE nominal data and thus it's the most appropiate to evaluate the factors that influence the cockfish catch rate. Furthermore, the LogNormal model had a lower AIC value than the Gamma model (Table 2). In summary, all the diagnostic plots and the Akaike information criterion supported the selection of the LogNormal as the best-fit model for the CPUE standardization.

All factors related with vessel characteristics were eliminated from the analysis, except for the Length factor and $\%$ of Operability factor, which represented a $2.7 \%$ and $2.8 \%$ of the total deviance explained by the LogNormal model, respectively. These were the lowest percentages of explained deviance in comparison with the other factors included in the model. The most important factor was Year which explained $43 \%$ of the total variability, followed by the Month factor and Depth factor which explained 19\% and $18 \%$, respectively. The factors related with the catch rate of the target species common hake and silver warehou represented $9 \%$ and $5 \%$ of the total variability explained by the model, respectively (Table 2 ).

The likelihood ratio test indicated significant differences between the models GLMM and GLM ( $L$. Ratio $=117.74$, df $=1, p<0.0001)$, being the mixed model the most parsimonious ( $\mathrm{AIC}=10430.32$ ). Therefore, the random factor Vessel contributed to the variability of the cockfish CPUE, being different between vessels. The variance component for this random factor was 0.2758 , equivalent to a coefficient of variation of $14.1 \%(=0.01981 / 2)$, while the residual variance was 0.2157 . All the factors evaluated in the GLMM were significant $(p<0.05)$. The residual and $\mathrm{q}-\mathrm{q}$ plots for the GLMM supported the use of the normal residual distribution on the log scale.

The standardized CPUE values and trends were similar for the Delta-GLM and Delta-GLMM with a LogNormal distribution and both models underestimated the nominal CPUE values (Figure 4). In all cases, the annual trend of the catch rate indicated an increase during the evaluated period. The nominal CPUE showed an increase of 57\% from 1986 to 2011, while the indices standardized by the GLM and GLMM did not differ significantly from that value, with increases of $61.1 \%$ and $60.7 \%$, respectively. The standardized annual catch rate showed fluctuating values between the 9 and $34 \mathrm{~kg} / \mathrm{hs}$ during the period 1986-1999. From the year 1999, the standardized CPUE trend showed an increase with a highest value of $59 \mathrm{~kg} / \mathrm{hs}$ in the year 2009. The fishing effort (effective fishing hours) showed an increase of $23 \%$ from the year 1986 to 2011. The effort increased from 1988 until the late 1990's, was highest in the 1998-2001 period, and then decreased somewhat towards the end of the study period (Figure 4).

Figure 5 shows the catch rate trend of cockfish estimated with the Lognormal GLM and GLMM, for the main factors that explained the variability of the data set. For the Month factor, the lowest values of catch rate were estimated in October and November with an average of $18 \mathrm{~kg} / \mathrm{hs}$, while the highest values of catch rate were obtained during autumn and winter months and they fluctuated between 34 and $42 \mathrm{~kg} / \mathrm{hs}$ (Figure $5 \mathrm{a}$ ).

Regarding bathymetry, the catch rate of cockfish was inversely related to depth, with the highest values of 56 $\mathrm{kg} / \mathrm{h}$ between 50 and $90 \mathrm{~m}$. (Figure $5 \mathrm{~b}$ ). The catch rate was also inversely related to the common hake and silver warehou CPUE levels (target species), with values ranging from 20 to $36 \mathrm{~kg} / \mathrm{h}$ and 31 to $18 \mathrm{~kg} / \mathrm{h}$, respectively 
Table 2. Deviance tables of the Binomial, LogNormal (logCPUE) and Gamma (CPUE) GLMs, Significant factors with a $\%$ of explained deviance equal or greater than 1\%; df: residual degrees of freedom; Res Dev: residual deviance; Dev Dif: deviance difference; \% exp dev: percentage of deviance explained by each factor; $P: p$ value refereed to an F probability; * highly significant.

Binomial model:

Dependent variable: probability of a non-zero cockfish catch; Distribution: binomial; Link function: Logit

\begin{tabular}{|c|c|c|c|c|c|}
\hline Factors & df & Res Dev & Dev Dif & $\%$ of $\exp d e v$ & $p$ \\
\hline Null Model & 9276 & 8002.3 & & & \\
\hline Year & 9251 & 7227.9 & 774.39 & 44.80 & $<0.001 *$ \\
\hline Month & 9240 & 6936.5 & 291.44 & 16.86 & $<0.001 *$ \\
\hline Depth & 9237 & 6736.1 & 200.37 & 11.59 & $<0.001^{*}$ \\
\hline CPUE of common hake & 9233 & 6657.5 & 78.58 & 4.55 & $<0.001 *$ \\
\hline CPUE of silver warehou & 9228 & 6417.9 & 239.6 & 13.86 & $<0.001 *$ \\
\hline Vessel lengths & 9223 & 6369.5 & 48.43 & 2.80 & $<0.001 *$ \\
\hline$\%$ of Operatibility & 9218 & 6273.9 & 95.58 & 5.53 & $<0.001^{*}$ \\
\hline Total explained deviance & & & 1728.39 & 21.59 & \\
\hline AIC value & & & & 6391.9 & \\
\hline $\mathrm{Chi}^{2}$ value $(0.95, \mathrm{df})$ & & & & 9442.47 & \\
\hline
\end{tabular}

LogNormal model (positive data set):

Dependent variable: $\log$ (CPUE) of cockfish; Distribution: normal; Link function: Identity

\begin{tabular}{|c|c|c|c|c|c|}
\hline Factors & df & Res Dev & Dev Dif & $\%$ of $\exp d e v$ & $p$ \\
\hline Null Model & 7838 & 2268.1 & & & \\
\hline Year & 7813 & 2039.6 & 228.54 & 42.90 & $<0.001^{*}$ \\
\hline Month & 7802 & 1936.5 & 103.07 & 19.35 & $<0.001 *$ \\
\hline Depth & 7799 & 1839.5 & 97.02 & 18.21 & $<0.001 *$ \\
\hline CPUE of common hake & 7795 & 1792.2 & 47.3 & 8.88 & $<0.001 *$ \\
\hline CPUE of silver warehou & 7790 & 1764.9 & 27.28 & 5.12 & $<0.001 *$ \\
\hline Vessel lengths & 7785 & 1750.5 & 14.36 & 2.70 & $<0.001 *$ \\
\hline$\%$ of Operatibility & 7780 & 1735.4 & 15.1 & 2.83 & $<0.001^{*}$ \\
\hline Total explained deviance & & & 532.67 & 23.49 & \\
\hline AIC value & & & & 10546 & \\
\hline $\mathrm{Chi}^{2}$ value $(0.95, \mathrm{df})$ & & & & 7986.31 & \\
\hline
\end{tabular}

Gamma model (positive data set):

Dependent variable: CPUE of cockfish; Distribution: Gamma; Link function: Log

\begin{tabular}{|c|c|c|c|c|c|}
\hline Factors & df & Res Dev & Dev Dif & $\%$ of exp dev & $p$ \\
\hline Null Model & 7838 & 10251.4 & & & \\
\hline Year & 7813 & 9089.1 & 1162.32 & 54.78 & $<0.001^{*}$ \\
\hline Month & 7802 & 8770.1 & 319.03 & 15.04 & $<0.001^{*}$ \\
\hline Depth & 7799 & 8439.1 & 330.95 & 15.60 & $<0.001 *$ \\
\hline CPUE of common hake & 7795 & 8315.8 & 123.28 & 5.81 & $<0.001^{*}$ \\
\hline CPUE of silver warehou & 7790 & 8269.5 & 46.3 & 2.18 & $<0.001^{*}$ \\
\hline Vessel lengths & 7785 & 8185.6 & 83.89 & 3.95 & $<0.001 *$ \\
\hline$\%$ of Operatibility & 7780 & 8129.7 & 55.95 & 2.64 & $<0.001 *$ \\
\hline Total explained deviance & & & 2121.72 & 20.70 & \\
\hline AIC value & & & & 74293 & \\
\hline $\mathrm{Chi}^{2}$ value $(0.95, \mathrm{df})$ & & & & 7986.31 & \\
\hline
\end{tabular}




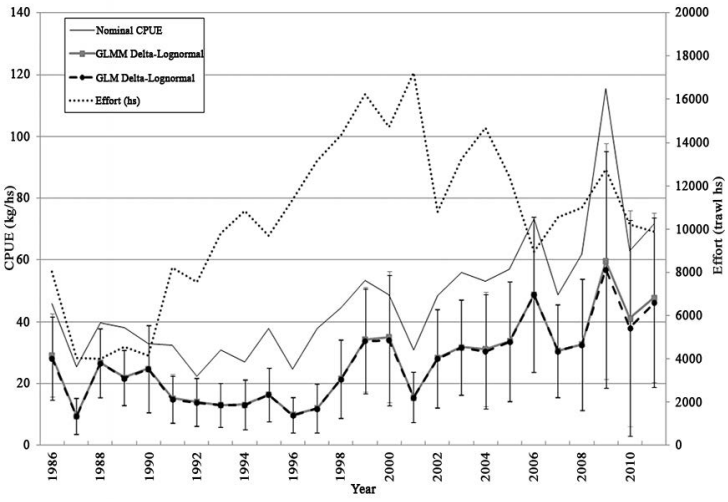

Figure 4. Nominal and standardized annual CPUE estimated with the Delta-GLM and Delta-GLMM, 1986-2011. The vertical bars indicated + standard deviation for GLMM (gray) and for GLM (black). The dotted line is the fishing effort in effective trawl hours.

(Figure 5c and Figure 5d). Concerning vessel characteristics, the catch rate did not show a clear pattern with regard to the Length factor, with stables values between 20 and $30 \mathrm{~kg} / \mathrm{h}$ and a maximum of $70 \mathrm{~kg} / \mathrm{h}$ just for the vessel length group of 31-35 m (Figure 5e). Finally, regarding vessel operability in the fishery, vessels with less than $4 \%$ of operability had the lowest catch rates, while the highest catch rate estimates correspond to vessels with the highest operatibility. However, there were a high variability, therefore, a clear pattern for the Operability factor was not observed (Figure 5f).

\section{DISCUSSION}

\section{Model Selection}

The LogNormal distribution model was the best to evaluate the catch rate variability of cockfish and the associated factors. This model registered the lowest AIC value, presented a good fit of the observed data and explained a $23.5 \%$ of the total variability (Table 2 ). This model selection agrees with other studies of chondrichthyans that are captured as bycatch which used the same error distribution for the positive data set (AIRES et al., 2008; MINISTRY FOR PRIMARY INDUSTRIES OF NEW ZEALAND, 2011; BRACCINI et al., 2011; BARNETT et al. 2012; CARLSON et al., 2012). Generally, the models used to standardize the CPUE explained a low percentage of the total variability of the data set. A possible explanation for that is the lack of information on environmental variables or the difficulty to identify and include all of the key variables that affect the catch rate (PUNT et al., 2000). In this study environmental variables and information about skipper experience, changes in the crew's vessels or changes in commercial interests were not readily available and so they were not included in the analysis.

The GLMM had the lowest AIC value and the likelihood ratio test indicated that the random effect Vessel was significant, thus the observations made within the same vessel were correlated. This is because the catch and effort data of each vessel are longitudinal data, which means that several measurements are made on the same experimental units over time. In fisheries science, in these cases the use of GLMMs is recommended (VENABLES and DICHMONT, 2004). Moreover, the random terms do not contribute to the fixed part of the mean, but the variance components associated with them inflate the variability of predictions in an appropriate way (VENABLES and DICHMONT, 2004; CRAWLEY, 2007). The analysis of abundance indices by GLM may underestimate the level of variability since it ignores the grouped nature of tows within vessels (HELSER et al., 2004; BAUM and BLANCHARD, 2010). In this stu$\mathrm{dy}$, the estimations of annual abundance indices from GLM and GLMM were similar as well as the associated variances (Figure 4). Therefore, although there is an effect of vessels in the variability of the estimates of the cockfish catch rate, this would be relatively low.

\section{YEAR FACTOR}

Regarding to the fixed effects variability, the temporal factors Year and Month, were the main factors that explained the variability of the data set. Generally, the Year factor is associated to annual fluctuations of the biomass of the stocks due to annual changes in the recruitment, growth, natural or fishing mortality or in the distribution pattern of the resource (HILBORN and WALTERS, 1992; MAUNDER and PUNT, 2004; HERNANDEZ and PERROTTA, 2006). Annual variations of catch rate occur with any of these changes and should be reflected in a high percentage of total deviance explained by the Year factor. In this study, although the Year factor had the most important contribution to the explained deviance, the annual fluctuations of the cockfish CPUE estimated by the models (Figure 4) cannot be only associated to natural changes of biomass. This is because the cockfish was not the target species and therefore catch rates may be influenced by several factors related with fleet behavior, market demands and abundance fluctuations of target species (M. hubbsi) that conduce to annual changes in the effort directionality to other resources such as the cockfish. The abundance peak in 2009 that is observed in the nominal CPUE and the CPUE estimated by 

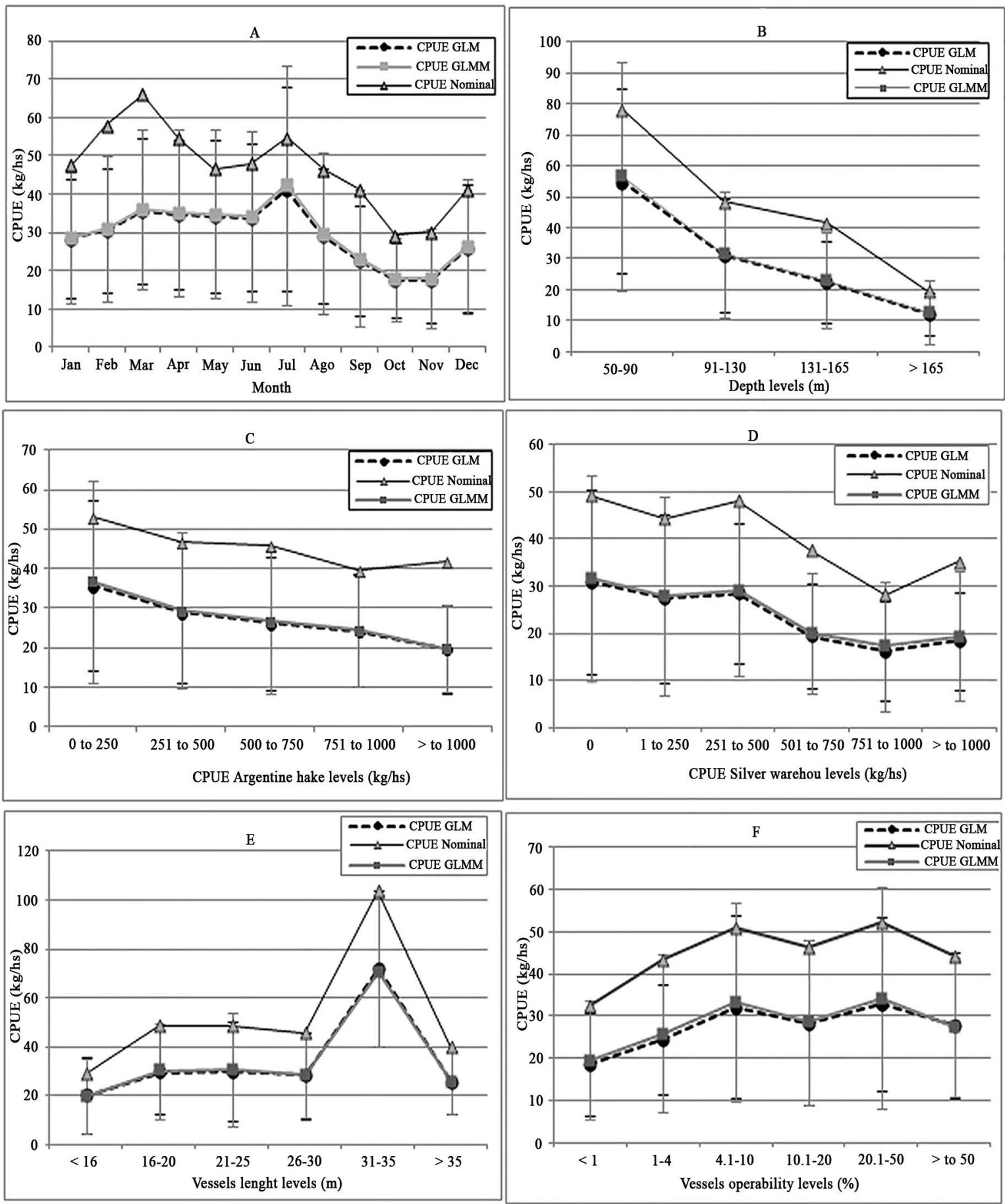

Figure 5. Nominal and standardized CPUE average for each level of the principal factors that explained the data set variability: (a) month, (b) depth, (c) CPUE common hake, (d) CPUE silver warehou, (e) vessels lenght and (f) vessels operability. The vertical bars indicated + standard deviation for GLMM (gray) and for GLM (black).

the models can be explained by the latest factors. During that year the landings of cockfish had an abruptly increase of $106 \%$ with respect to the annual mean for the $2000-2011$ period (Figure 1). The $60 \%$ of the total catches of cockfish during 2009 were recorded only by 3 vessels, in which the cockfish represented between $35 \%$ and $68 \%$ with respect to the total catches of common hake (target species). Figure 4 shows an increase of annual CPUE that is accompanied of 
an increase in the variability of the estimates since 1999. This would be reflecting the variability in catch rates of cockfish for the different fishing trips during those years. This high variability would be associated to the changes in the effort directionality of some vessels to areas where the cockfish is more abundant and thus higher yields than the rest of fleet are obtained.

\section{Depth And Month Factors}

In this study, the low percentage of the total variability explained by the models could be related to the lack of a spatial factor (fishing grounds). Although the main areas of distribution of the cockfish in the SMG have been described (DI GIÁCOMO, 1992), accurate information of the fishing areas of each fishing trip was not available for this study. Such information would have allowed us to evaluate the overlap between the fleet and the cockfish distribution. However, other factors (Depth and Month) might be including indirectly the variability of catch rates due to the spatial scale. One of the most important factors was Depth (Table 2). In SMG the highest densities of cockfish are present in the most coastal strata (between 20 and 90 $\mathrm{m}$ of depth), with a discontinuous distribution following the contours of the $100 \mathrm{~m}$ isobath (DI GIÁCOMO and PERIER, 1991; DI GIÁCOMO, 1992). In these depth strata there are two important concentrations of this species, one in the northern part and another one in the southern part of SMG, which are associated to the availability of benthic resources (main prey of cockfish) (DI GIÁCOMO 1992; Di GIÁCOMO and PERIER, 1996). This description agrees with the estimates obtained from the models that show that the highest catch rates of cockfish are in the lowest trawls depths, between 50 and $90 \mathrm{~m}$ (Figure 5b).

The Month factor is usually related to changes of the stocks' abundance throughout the year (spawning aggregations, migrations, changes in prey availability). In this work, Month was other of the most influential factors on catch rates (Table 2), but in this case the monthly trend of the estimated CPUE (Figure 5a) would be mostly related to the spatial dynamics of the fleet according to season and the closed season implemented in the SMG, rather than to variations of the cockfish abundance. Since 1997, a closed season area was determined to the north of latitude $41^{\circ} 30^{\prime}$ 'S during October and November, with the goal of protecting the reproductive aggregations of common hake. Precisely, the lowest estimates of cockfish CPUE were obtained during those months (Figure 5a) because the fleet has restricted access to those areas. Therefore, this demonstrates how a management measure for the target species would protect indirectly the cockfish population, at least in the northern zone where there are the main areas of breeding, reproduction and foraging (DI GIÁCOMO, 1992, DI GIÁCOMO and PERIER, 1994).

In turn, the estimates of the monthly cockfish CPUE demonstrate that their catches are subject to the fleet dynamics searching the target species. A seasonal pattern for common hake yields has been described in SMG where the highest values are present during the spring-summer months while a reduction of catch rates occur during the winter months (FLOWERS and ROA, 1975; WILLIAMS et al., 2010). Assessments of the fleet dynamics using satellital telemetry have shown that the fleet spread over relatively shallow areas in SMG during autumn and winter (WILLIAMS et al., 2010, ROMERO et al., 2013). This dispersion is due to the reduction of common hake yields which would motivate skippers to seek better catches in more coastal and shallow waters. This is in accordance with the results of this study that showed that the highest values of cockfish CPUE are obtained during autumn and winter (from March to July) (Figure 5a) as a result of the overlap between the fleet and the cockfish distribution areas. Therefore, the high percentage of deviance explained by the Month factor would be related to this dynamics rather than seasonal variations of the species abundance.

\section{COMMON HAKE AND SILVER WAREHOU CPUE FACTORS}

Figure 5c shows that the highest values of cockfish CPUE are estimated for the lower levels of common hake CPUE. The relationship between this factor and the catch rate of cockfish is closely related to the aforementioned explanation for the Month factor and the fleet dynamics to seek the common hake. The fleet has incorporated the silver warehou, Seriolella porosa, as seasonal resource during the last period of the fishery (2000-2011). The catches of silver warehou have abruptly increased, reaching higher values than the cockfish landings in the SMG during this time (MILLAN, 2011) (Figure 1). Therefore, silver warehou CPUE factor was evaluated in the model to determine the influence of this seasonal fishery on the catch rate of cockfish. However, although it was included in the model, it was one of the factors that less explained the variability of the data (Table 2) and the highest estimates of cockfish CPUE occurred for the lowest levels of silver warehou CPUE (Figure 5d). One possible explanation for this tendency could be that the vessels who caught silver warehou 
do not overlap with the distribution areas of cockfish. This hypothesis is supported because the fleet leads its effort to the silver warehou mainly during August and September at depths greater than $100 \mathrm{~m}$ (PERIER and DI GIÁCOMO, 2002; ROMERO et al., 2013) where the lowest catch rate of cockfish were estimated. Therefore, we may conclude that the commercial exploitation of silver warehou is not a relatively important factor for the cockfish bycatch.

\section{Vessels LengthS FACTOR}

Vessel Length was the factor with the highest explained deviance out of all the factors related with vessel characteristics, therefore it was included in the models. However, the percentage of total deviance explained by this factor was lower than the contribution of other factors (Table 2). The estimates of the cockfish CPUE were similar for all levels, except for the vessel lengths between 31 and $35 \mathrm{~m}$ which presented an increase in the CPUE estimate with values around $70 \mathrm{~kg} / \mathrm{h}$ (Figure $5 \mathrm{e}$ ). This level includes some vessels that led the effort to the concentration areas of the cockfish, thus this factor would be representing the variability in catchability of vessels due to changes in the fishing strategy.

\section{VESSELS OPERABILITY FACTOR}

DI GIACOMO and PERIER (1992) analyzed the declining catches of common hake in SMG fishery from 1971 to 1989 and attributed them to a decline of the fleet efficiency due to instability of skippers and crews, fleet deterioration and low levels of operability and permanence of vessels in the fishery. The present study evaluated the effect of some of those factors on the cockfish catch rates, under the assumption that by affecting catch rates of common hake, they would be indirectly influencing catch rates of cockfish. Even though the histograms of operability and permanence (Figure 3) confirmed that the fleet was unstable during the studied period, only the $\%$ of Operability was included in the models and it had a low contribution to the total explained variability without showing a clear pattern with the cockfish CPUE (Figure 5f). Therefore, we cannot assume that the variability in catch rates of cockfish was due to these factors. Experience of the skipper and crews to handle the fishing gear and the technological equipment of vessels could be relevant factors that explain the variability in catch rates (MAUNDER and PUNT, 2004; MAUNDER et al. 2006) but they could not be evaluated by the models due to the lack of information in the data set.

\section{CONCLUSIONS}

The fishery has gone through different periods since its beginning in 1971. Although common hake has been always the main commercially exploited species, the fleet has diversified its catches by incorporating other complementary resources such as hoki (Macroronus magellanicus), the flounders (Paralichthys spp.), Argentine seabass (Acanthistius patachonicus), Argentine sandperch (Pseudopercis semifasciata), Pink cusk-eel (Genypterus blacodes), smooth hound shark (Mustelus schmitti), silver warehou (Seriolella porosa) and several skate species (family Rajidae) (PERIER and DI GIÁCOMO, 2002a, 2002b; ESTALLES et al., 2011; PERIER et al., 2011; ROMERO et al., 2013). These variations in landings along different periods are the result of changes in the behaviour of the fleet during different years and fishing seasons; thus indicating that the intensity and directionality of effort to the target species $M$. hubbsi and complementary species were changing throughout the fishery history.

The standardized CPUE has been extensively used as an index of relative abundance for several chondrichthyan species caught as bycatch (PUNT et al., 2000; BAUM and BLANCHARD, 2010; CARVALHO et al., 2010; BRACCINI et al., 2011; CARLSON et al., 2012; TRAVASSOS TOLOTTI et al., 2013). However, its use must be evaluated considering the particular characteristics of each regional fishery. This study shows that the catch rate of cockfish is subject to the fleet dynamic searching the target species and how changes in fleet behaviour affect the cockfish catches. The results allowed us to evaluate which are the factors of the fishery that affect the catch rate of cockfish; however the standardized CPUE as an index of relative abundance must be used with caution. The standardization of cockfish CPUE was subject to the lack of a homogeneous distribution of the fishing effort during different years, months and vessels. The increasing trend of CPUE and landings would be indicating an increase in fishing power or effort directionality to the cockfish in the last decade instead of an increase in population abundance.

Similar CPUE and landings trends have been documented for a species of the same genus, C. milli of New Zealand. An adaptative management program with total allowable commercial catch (TACC) was implemented for this species, after it had been declared overfished because of a severe decline of landings during the mid of $80 \mathrm{~s}$. A decade later the landings increased and reached historical 
peaks during 2007-2010 (FRANCIS, 1998; MINISTRY FOR PRIMARY INDUSTRIES OF NEW ZEALAND, 2011). In turn, the standardized CPUE trend and biomass estimates for $C$. milli showed an increase in New Zealand (MINISTRY FOR PRIMARY INDUSTRIES OF NEW ZEALAND, 2011). For C. callorynchus, it is recommended to continue monitoring the evolution of landings after the increase in recent years. Besides, it is recommended to estimate the biomass from fisheries-independent surveys to evaluate if there has been a real increase in the biomass since 1986 as might be indicating the standardized CPUE calculated in this study.

Finally, it is important to improve the available information about the spatial dynamics of the fleet to assess its overlap with the distributions areas of the species. This will improve the estimates of the standardized CPUE in order to use it as an index of relative abundance because it would be possible to establish objective criteria to select the fishing trips with directional effort to cockfish from the data set (PUNT et al., 2000; BRACCINI et al., 2011).

\section{ACKNOWLEDGEMENTS}

This work was developed in the context of the Proyect UNCo SI 04/M020 "Pez gallo, tiburones y rayas del Golfo San Matías: Hacía una explotación sustentable" and the Project Agencia PICT-2011-2597 “¿Es sustentable la explotación pesquera de los tiburones, las rayas y el pez gallo? El golfo San Matías como caso de estudio". The authors would also like to acknowledge the Consejo Nacional de Investigaciones Científicas y Tecnológicas (CONICET) for providing a fellowship to J.F. Bernasconi and to Daniel Millan of the Dirección de Pesca de la Provincia de Rio Negro for providing fishery statistics. We also thank to Lic. Vanesa Reyes for helping us with translation of the manuscript.

\section{REFERENCES}

AKAIKE, H. Information theory as an extension of the maximum likelihood principle. In: PETROV, B.; CSAKI, F. (Eds.). Proceedings of the Second International Symposium on Information Theory. Budapest: Akademiai Kiado, 1973. p. 267-281.

AIRES-da SILVA, A. M.; HOEY, J. J.; GALLUCCI, V. F. A historical index of abundance for the blue shark (Prionace glauca) in the western North Atlantic. Fish. Res., v. 92, n. 1 p. 41-52, 2008 .

ALARCON, C.; CUBILlOS, L. A.; ACUÑA, E. Length-based growth, maturity and natural mortality of the cockfish Callorhinchus callorhynchus (Linnaeus, 1758) off Coquimbo, Chile. Environ. Biol. Fish., v. 92, n. 1, p. 65-78, 2011.
BARNETT, L. A. K.; EBERT, D. A.; CAILLIET, G. M. Evidence of stability in a chondrichthyan population: case study of the spotted ratfish Hydrolagus colliei (Chondrichthyes: Chimaeridae). J. Fish Biol., v. 80, n. 5, p. 1765-1788, 2012.

BAUM, J.K.; MYERS, R.A.; KEHLER, D.G.; WORM, B.; HARLEY, S.J.; DOHERTY, P.A. Collapse and conservation of shark populations in the Northwest Atlantic. Science 299, 389-392, 2003.

BAUM, J. K.; MYERS, R. A. Shifting baselines and the decline of pelagic sharks in the Gulf of Mexico. Ecol. Lett., v. 7, n. 2, p. 135-145, 2004.

BAUM, J. K.; BLANCHARD, W. Inferring shark population trends from generalized linear mixed models of pelagic longline catch and effort data. Fish. Res., v. 102, n. 3, p. 229-239, 2010 .

BRACCINI, J. M.; ETIENNE, M. P.; MARTELL, S. J. D. Subjective judgement in data subsetting: implications for CPUE standardization and stock assessment of non-target chondrichthyans. Mar. Fresh. Res., v. 62, n.6, p. 734-743, 2011.

BRANDER, K. Disappearance of common skate Raia batis from Irish Sea. Nature, v. 290, p. 48-49, 1981.

BROMHEAD, D.; CLARKE, S.; HOYLE, S.; MULLER, B.; SHARPLES, P.; HARLEY, S. Identification of factors influencing shark catch and mortality in the Marshall Islands tuna longline fishery and management implications. J. Fish Biol., v. 80, n. 5, p. 1870-1894, 2012.

BRYNJARSDOTTIR, J.; STEFANSSON, G. Analysis of cod match data form Icelandic groundfish surveys using generalized linear models. Fish. Res., v. 70, p. 195-208, 2004.

CAMHI, M. D.; PIKITCH, E. K.; BABCOCK, E. A global overview of commercial fisheries for open ocean sharks. In: Camhi, M. D., Pikitch, E. K.; Babcock, E. A. (Eds.). Sharks of the Open Ocean: Biology, Fisheries and Conservation. Oxford: Blackwell Publishing, 2008.

CASEY, J. M.; MYERS, R. A. Near extinction of a large, widely distributed fish. Science, v. 281, n. 5377, p. 690-692, 1998.

CARLSON, J. K.; HALE, L. F.; MORGAN, A.; BURGESS, G. Relative abundance and size of coastal sharks derived from commercial shark longline catch and effort data. J. Fish Biol., v. 80, n. 5, p. 1749-1764, 2012.

CARVALHO, F. C.; MURIE D. J.; HAZIN, F. H.; HAZIN, H. G., LEITE-MOURATO, B.; TRAVASSOS, P.; BURGESS, G. $\mathrm{H}$. Catch rates and size composition of blue sharks (Prionace glauca) caught by the Brazilian pelagic longline fleet in the southwestern Atlantic Ocean. Aquat. Living Resour., v. 23, p. 373-385, 2010.

CRAWLEY, M. J. The R book. (Ed.). Chichester: John Wiley and Sons, 2007. $942 \mathrm{p}$.

DICK, E. J. Beyond 'lognormal versus gamma': discrimination among error distributions for generalized linear models. Fish. Res., v. 70, n. 2, p. 351-366, 2004.

DI GIÁCOMO, E. E.; PERIER, M. R. Evaluación de la biomasa y explotación comercial del pez gallo (Callorhynchus callorhynchus) en el Golfo de San Matías, Argentina. Frente Marítimo, v. 9, n. A, p. 7-13, 1991.

DI GIÁCOMO, E. E. Distribución de la población del pez gallo (Callorhynchus callorhynchus) en el Golfo de San Matías, Argentina. Frente Marítimo, v. 12, n. A, p. 113-118, 1992. 
DI GIÁCOMO, E. E.; PERIER, M. R. Retracción de la pesquería demersal del golfo San Matías: escasez de recursos o disminución de la eficiencia? Frente Marítimo, v. 11, p. 7-13, 1992.

DI GIÁCOMO, E. E., CALVO, J.; PERIER, M. R.; MORRICONI, E. R. Spawning aggregations of Merluccius hubbsi, in patagonian waters: evidence for a single stock. Fish. Res., v. 16, n. 1, p. 9-16, 1993.

DI GIÁCOMO, E. E.; PERIER, M. R. Reproductive biology of the cockfish, Callorhynchus callorhynchus (Holocephali: Callorhynchidae), in Patagonian waters (Argentina). Fish. Bull., v. 92, p. 531-539, 1994.

DI GIÁCOMO, E. E.; PARMA, A. M., ORENSANZ, J. M. Food consumption by the cock fish, Callorhinchus callorynchus (Holocephali: Callorhynchidae), from Patagonia (Argentina). Environ. Biol. Fishes., v. 40, p. 199-211, 1994.

DI GIACOMO, E. E.; PERIER, M. R. Feeding habits of cockfish, Callorhinchus callorhynchus in patagonian Waters, Argentina. Mar. Fresh. Res., v. 47, p. 801-8, 1996.

DULVY, N. K.; METCALFE, J. D.; GLANVILLE, J.; PAWSON, M. K., REYNOLDS, J. D. Fishery stability, local extinctions, and shifts in community structure in skates. Conserv. Biol., v. 14, n. 1, p. 283-293, 2000.

Estalles, M.; Coller N. M.,; Perier, M. R.; Di Giácomo, E. E. Skates in the demersal trawl fishery of San Matías Gulf, Patagonia: species composition, relative abundance and maturity stages. Aquat. Living Resour., v 24, p. 193-199, 2011.

FERRETTI, F.; OSIO, G. C.; JENKINS, C. J.; ROSENBERG, A. A.; LOTZE, H. K. Long-term change in a meso-predator community in response to prolonged and heterogeneous human impact. Sci. Rep., v. 3, p. 1057, 2013.

FIGUEIREDO, J. L. Manual de peixes marinhos do Sudeste do Brasil. Introdução. Cações, raias e quimeras. São Paulo: Museu de Zoologia, University of São Paulo, 1977. 104 p.

FLOWERS, J.; ROA, H. Report on investigation in the Gulf of San Matías and the Gulf of San Jorge. FAO Report FI:DP: Arg.65, 510/3, 1975. 64 p.

FRANCIS, M. P. Spatial and temporal variation in the growth rate of elephantfish (Callorhinchus milii). N.Z. J. Mar. Freshw. Res., v. 31, n. 1, p. 9-23, 1997.

FRANCIS, M. P. New Zealand shark fisheries: development, size and management. Mar. Freshw. Res., v. 49, n. 7, p. 579-591, 1998.

FREER, D. W. L.; GRIFFITHS, C. L. Estimation of age and growth in the St. Joseph Callorhinchus capensis (Dumeril). So. Afr. J. Mar. Sci., v. 13, n. 1, p. 75-82, 1993.

FOX, J.; WEISBERG, S. An R Companion to Applied Regression. 2. ed. Thousand Oaks: Sage, 2011. 472 p.

GAVARIS, S. Use of a multiplicative model to estimate catch rate and effort from commercial data. Can. J. Fish. Aquat. Sci., v. 37 , p. $2272-2275,1980$

GAGLIARDINI, D. A., RIVAS, A. L. Environmental characteristics of San Matías Gulf obtained from LANDSAT-TM and ETM+ DATA. Gayana, v. 68, n. 2, p. 186-193, 2004.

HELSER, T. E.; PUNT, A. E.; METHOT, R. D. A generalized linear mixed model analysis of a multi-vessel fishery resource survey. Fish. Res., v. 70, n. 2, p. 251-264, 2004.

HERNANDEZ, D. R.; PERROTTA, R. G. Influencia de las Interacciones con el factor año en los índices anuales de abundancia obtenidos por modelos lineales generales utilizando datos de captura por unidad de esfuerzo. Rev. Invest. Pesq., v. 18, p. $57-73,2006$.
HILBORN, R.; WALTERS, C. J. (Eds.). Quantitative Fisheries Stock Assessment: Choice, Dynamics and Uncertainty. New York: Chapman and Hall, 1992. p. 570.

HOENING, J. M.; GRUBER, S. H. Life-history patterns in the elasmobranchs: implications for fisheries management. In: PRATT, H. L.; GRUBER, S. H.; TANIUCHI, T. (Eds.), Elasmobranchs as living resources: advances in the biology, ecology, systematics and the status of the fisheries. U. S. Dep. Commer., NOAA Tech. Rep. NMFS 90, 1990. p. 1-16.

HOLDEN, M. J. Are long-term sustainable fisheries for elasmobranches possible? J. Reun. Cont. Int. Explor. Mer., v. 164, p. 360-370, 1973.

IHAKA, R.; GENTLEMAN, R. R: a language for data analysis and graphics. J. Comput. Graph. Stat., v. 5, p. 299-314, 1996.

MAUNDER, M.; PUNT, A. Standardizing catch and effort data: a review of recent approaches. Fish. Res., v. 70, p. 141-159, 2004.

MAUNDER, M. N.; SIBERT, J. R.; FONTENEAU, A.; HAMPTON, J.; KLEIBER, P.; HARLEY, S. J. Interpreting catch per unit effort data to assess the status of individual stocks and communities. ICES J. Mar. Sci., v. 63, n. 8, p. 1373-1385, 2006.

MC CULLAGH, P.; NELDER, J. A. Generalized Linear Models. 2. ed. New York: Chapman \& Hall, 1989. 511 p.

MILLAN, D. Anuario de Estadísticas Pesqueras de la Provincia de Río Negro. Departamento Policía de Pesca, Dirección de Pesca, San Antonio Oeste, 2011.

MINAMI, M.; LENNERT-CODY, C. E.; GAO, W.; ROMAN-VERDESOTO, M. Modeling shark bycatch: the zero-inflated negative binomial regression model with smoothing. Fish. Res., v. 84, n. 2, p. 210-221, 2007.

MINISTRY FOR PRIMARY INDUSTRIES OF NEW ZEALAND. Report from the Fisheries Assessment Plenary, May 2011: stock assessments and yield estimates. Wellington, 2011. p. 196-215.

MIRANDA, L. V.; VOOREN, C. M. Captura e esforço da pesca de elasmobrânquios demersais no sul do Brasil nos anos de 1975 a 1997. Frente Marítimo, v. 19, n. B, p. 217-231, 2003.

MOURA, T.; FIGUEIREDO, I.; MACHADO, P. B.; SERRANO GORDO, L. Growth pattern and reproductive strategy of the holocephalan Chimaera monstrosa along the Portuguese continental slope. J. Mar. Biol. Ass. U.K., v. 84, n. 4, p. 801-804, 2004.

LO, N. C.; JACOBSON, L. D.; SQUIRE, J. L. Indices of relative abundace from fish spotter data based on delta lognormal models. Can. J. Fish. Aquat. Sci., v. 49, p. 2515-2516, 1992.

LÓPEZ, H. L.; SAN ROMÁN, N. A.; DI GIÁCOMO, E. E. On the South Atlantic distribution of Callorhinchus callrhynchus (Holocephali: Callorhynchidae). J. Appl. Ichthyol., v. 16, p. 39,2000

ORTIZ, M.; AROCHA, F. Alternative error distribution models for standardization of catch rates of non-target species from a pelagic longline fishery: billfish species in the Venezuelan tuna longline fishery. Fish. Res., v. 70, n. 2/3, p. 275-294, 2004.

PERIER, M. R.; DI GIACOMO, E. E. El Savorín Seriolella porosa como un recurso estacional en el Golfo San Matías, República Argentina. Rev. Inves. Desar. Pesq., v. 15, p. 15- 26, 2002 a.

PERIER, M. R.; DI GIACOMO, E. E. Distribución, abundancia y reproducción de Paralichthys isosceles, P. patagonicus y Xistrerus rasile (Pleuronectiformes: Bothidae) en aguas patagónicas, Argentina. IBMP-Serie de Publicaciones, v. 1, p. $32-39,2002 b$ 
PERIER, M. R.; ESTALLES, M.; COLLER, N. M.; SUAREZ, M. N.; MORA, G. J.; DI GIACOMO, E. E. Chondrichthyans of the San Matías Gulf, Patagonia, Argentina. Rev. Mus. Argentino Cienc. Nat., v. 13, n. 2, p. 213-220, 2011.

PINHEIRO, J.; BATES, D.; DEBROY, S.; SARKAR, D. The R Development Core Team. nlme: Linear and Nonlinear Mixed Effects Models. R package version 3. p. 1-105, 2012.

PUNT, A. E.; WALKER, T. I.; TAYLOR, B. L., PRIBAC, F. Standardization of catch and effort data in a spatially-structured shark fishery. Fish. Res., v. 45, n. 2, p. 129-145, 2000.

RIVAS, A. L.; BEIER, E. J. Temperature and salinity fields in the Northpatagonic Gulfs. Oceanol. Acta, v. 13, n. 1, p. 15-20, 1990.

ROMERO, M. E.; OCAMPO, R. M., WILLIAMS, G.; NARVARTE, M.; GAGLIARDINI, D. A.; GONZALEZ, R. Understanding the dynamics of an enclosed trawl demersal fishery in Patagonia (Argentina): A holistic approach combining multiple data sources. Fish. Res., v. 140, p. 73-82, 2013.

SANCHEZ, R. P.; NAVARRO, G.; ROZYCKI, V. Estadísticas de la Pesca Marina en la Argentina. Evolución de los desembarques 1898-2010. Ministerio de Agricultura, Ganadería y Pesca de la Nación. Buenos Aires, 2012. 528 p.

SIMPFENDORFER, C. A.; HUETER, R. E.; BERGMAN, U.; CONNETT, S. M. H. Results of a fishery-independent survey for pelagic charks in the western North Atlantic, 1977-1994. Fish. Res., v. 55, p. 175-192, 2002.

STEVENS, J. D.; BONFIL, R.; DULVY, N. K.; WALKER, P. A. The effects of fishing on sharks, rays and chimaeras (chondrichthyans), and the implications for marine ecosystems. ICES J. Mar. Sci., v. 57, n. 3, p. 476-494, 2000.
TRAVASSOS TOLOTTI, M.; TRAVASSOS, P.; FREDOU, F. L.; WOR, C.; ANDRADE, H. A., HAZIN, F. Size, distribution and catch rates of the oceanic whitetip shark caught by the Brazilian tuna longline fleet. Fish. Res., v. 143, 136-142, 2013.

VENABLES, W. N.; DICHMONT, C. M. GLMs, GAMs and GLMMs: an overview of theory for applications in fisheries research. Fish. Res., v. 70, n. 2/3, p. 319-337, 2004.

VIGNAUX, M. Catch per unit effort (CPUE) analysis of west coast South Island Cook Strait spawing hoki fisheries, 1987-93. Wellington: New Zealand Fisheries Association Research Document No.94/11, 1994.

VOOREN, C. M.; KLIPPEL, S. Ações para a conservação de tubarões e raias no sul do Brasil. Porto Alegre: Igaré, 2005. $262 \mathrm{p}$.

WALKER, T. Can shark resources be harvested sustainably? A question revisited with a review of shark fisheries. Mar. Freshw. Res., v. 49, n. 7, p. 553-572, 1998.

WILLIAMS, M.; SAPOZNIK, M.; OCAMPO, R. M.; SOLIS, M.; NARVARTE, M., GONZALEZ, R.; ESTEVES, J. L.; GABLIARDINI, D. Comparison of AVHRR and SeaWiFS imagery with fishing activity and in situ data in San Matías Gulf, Argentina. Int. J. Remote Sens., v. 31, n. 17-18, p. 45314542, 2010.

ZUUR, A. F.; IENO, E. N.; WALKER, N. J.; SAVELIEV, A. A.; SMITH, G. M. Mixed Effects Models and Extensions in Ecology with R. New York: Springer, 2009. 574 p. 